\title{
Comparative Effect of Cold Hydro Stem-Bark Extract of Erythrophleum Suaveolens on Gastrointestinal Muscle of Rabbit Jejunum (Oryctolagus Cuniculus)
}

\author{
Ogundeko O Timothy ${ }^{1}$, Ramyil M Seljul ${ }^{2, *}$, Idyu C Vivian ${ }^{3}$, Idyu I Isaiah ${ }^{4}$ \\ ${ }^{1}$ Department of Pharmacology and Therapeutics, College of Health Sciences, Bingham University, Jos, Nigeria \\ ${ }^{2}$ Department of Medical Microbiology, College of Health Sciences, Bingham University, Jos, Nigeria \\ ${ }^{3}$ Department of Clinical Pharmacy, Faculty of Pharmaceutical Sciences, University of Jos, Nigeria \\ ${ }^{4}$ Department of Pharmacology, Faculty of Pharmaceutical Sciences, University of Jos, Nigeria \\ *Corresponding author: crownramyil@yahoo.com
}

Received June 09, 2014; Revised June 19, 2014; Accepted June 19, 2014

\begin{abstract}
Detailed investigations on plant materials especially such that are already in use especially by tradiopractitionals should not be taken with levity. The effect of cold water crude extract of stem-bark of Erythrophleum suaveolens on the activity of an isolated rabbit jejunum was studied. Reference drugs (Adrenaline and Isoprenaline) were used both in the presence and absence of $E$. suaveolens extract. Preliminary pharmacological investigation of the extract revealed inhibitory effects. However, the relaxative effect of the extract on isolated smooth muscle was confirmed from its cumulative response on Rabbit jejunum in which there was a graded inhibition of the jejunal contraction even up to $95 \%-95.5 \%$. The result of the study therefore suggest that the extract has the potential of been develop as an anti-motility agent as a remedy for GIT system related problems.
\end{abstract}

Keywords: Erythrophleum suaveolens, Oryctolagus cuniculus, Gastrointestinal Muscle, Jejunum, Inhibitory effect

Cite This Article: Ogundeko O Timothy, Ramyil M Seljul, Idyu C Vivian, and Idyu I Isaiah, "Comparative Effect of Cold Hydro Stem-Bark Extract of Erythrophleum Suaveolens on Gastrointestinal Muscle of Rabbit Jejunum (Oryctolagus Cuniculus).” American Journal of Pharmacological Sciences, vol. 2, no. 3 (2014): 52-55. doi: 10.12691/ajps-2-3-2.

\section{Introduction}

The knowledge of the effect(s) of substances to be used as medicines on different body systems is very vital in drug development vis - a vis drug safety [1]. E. suaveolens is a perennial tree of about $30 \mathrm{~m}$ in height, slightly buttressed, often low-branching and producing a dense spreading crown. The plant is one of the useful plants of west tropical Africa which is referred to by various names by natives [2-7]. As drinks, the bark is used as alcoholic and stimulant as well as laxative, abortifacient, antibiotics, and in the treatment of oedema, gout, rheumatism amongst others in the area of medicine [8]. Investigations carried out on the isolated ileum tissue of the guinea-pig (Cavia porcellus) by running a doseresponse relationship of the agonist test drugs (Acetylcholine, Histamine, and Barium Chloride) in the presence of the cold water crude extract of stem-bark of Erythrophleum suaveolens ascertained antagonist nature of the extract with a shift to the right [9]. The determination of $L D_{50}$ on albino mice gave an insight into safety margin of E. suaveolens $(223.8 \pm 0.05 \mathrm{mg} / \mathrm{kg}$ body weight) falling within the very toxic range as defined by Hodge and Sterner (1947) categorization [10].

It is a well-established observation that inhibition in the small intestine is mediated by $\alpha$ - and $\beta$-adrenoreceptors $[11,12]$. In the guinea-pig ileum, it would seem that the actions of adrenaline and nor-adrenaline are mainly on neuronal elements $[13,14,15]$, whereas the effect of Isoprenaline is mainly on the muscle [13]. Evidence, however showed that $\alpha$-adrenoreceptors are also situated on the smooth muscle cells in the guinea-pig taenia coli and the rabbit small intestine, [16,17].

The foregoing findings have been further analyzed by examining the effects of phenoxy-benzamine and propranolol on the inhibitory actions of catecholamines on acetylcholine release and on the responses of the longitudinal muscle of the guinea-pig ileum to electrical stimulation. Preliminary reports of some of the results have been made to the Pharmacological and Physiological Societies $[18,19,20]$ and to the International Symposium on Gastro-Intestinal Motility in September, 1967 [21]. According to Couper in 2007, in addition to neuronal muscarine receptors, the guinea pig Ileum contains postsynaptic muscarine receptors which mediate the contraction of the smooth muscle [22].

\subsection{Statement of Problem}

Investigations carried out on the isolated ileum tissue of the guinea-pig (Cavia porcellus) by running a doseresponse relationship of agonist test drugs (Acetylcholine, Histamine, and Barium Chloride) in the presence of the cold water crude extract of stem-bark of Erythrophleum 
suaveolens ascertained antagonist nature of the extract with a right shift [9].

Detailed investigations on plant materials especially such that are already in use especially by tradiopractitionals should not be taken with levity. As a result of need for further confirmation of the blockade / inhibitory effect of cold water bark extract of E. suaveolens on other smooth muscles of the GIT.

\subsection{Aims and Objective}

The objective of this study is to investigate the effect of cold water extract of the stem-back of E. suaveolens on the rhythmic activity of an isolated rabbit's jejunum in comparison with the activity of selected standard drugs.

\section{Materials and Methods}

\subsection{Plant Preparation and Extraction}

Stem-back of Erythrophleum suaveolens were collected from Buruku Local Government area of Benue State, Nigeria. Identification and authentication were done by a plant taxonomist with the Federal School of Forestry, $\mathrm{Mr}$ Okonkwo Jos Plateau State, Nigeria and Professor S.W Husseni of the Department of Botany, University of Jos, Nigeria.

The bark was dried under the shade, in the Pharmacology Research Laboratory of the University of Jos, Nigeria. Sample was pulverized using wooden Mortar and Pestle according to the method of Ibrahim et al. (1984); Audu et al. (2001). The pulverized was stored at room temperature until required (Idyu et al, 2014a). $100 \mathrm{~g}$ of powdered stem-bark of the plant was weighed out in $1000 \mathrm{ml}$ capacity Pyrex glass beaker. This was dissolved in $200 \mathrm{ml}$ of distilled water according to the method of Audu et al. (2001). The mixture was allowed to stand for 24 hours at ambient room temperature. Mixture was stirred with a glass rod and then filtered through Whatman number one filter paper, using suction pump. The filtrate was concentrated in a water bath at a temperature of $80 \pm 1.0^{\circ} \mathrm{C}$ until a reddish, sticky extract was obtained. This gave a yield of $6.125 \mathrm{~g}$ of the extract from $100 \mathrm{~g}$ powdered sample. The recovered extract was stored in the Refrigerator at $-4^{\circ} \mathrm{C}$ (Idyu et al, 2014a). $1.0 \mathrm{~g}$ of crude water extract was weighed and dissolved in $10 \mathrm{ml}$ of distilled water to give a stock concentration solution of $1 \times 10^{-1} \mathrm{~g} / \mathrm{ml}(100 \mathrm{mg} / \mathrm{ml})$. Other concentration used for the test were prepared by diluting $1 \mathrm{ml}$ of stock solution in $9 \mathrm{ml}$ of distilled water (1:9) to give $1 \times 10^{-2} \mathrm{~g} / \mathrm{ml}$. Various concentrations were obtained through serial dilutions of the series as appropriate throughout the experiment.

\subsection{Animals and Tissue Preparation}

Adult sized rabbits (3.8-4.5 kg) of both sexes American chinchilla (Oryctolagus cuniculus) were purchased in cages from the Veterinary Research Institute, Vom, Nigeria. These were allowed to acclimatize, fed with spinach, cabbages and clean water ad libitum for 7 days, maintained at NEV temperature $\left(26-28^{\circ} \mathrm{C}\right)$ and deprived of food 24 hours before commencement of experiment.

The rabbits were sacrificed by a blow to the head and exsanguination after which the abdomen was cut open and segment of the jejunum dissected, trimmed to remove adhering mesentery, divided into $2-3 \mathrm{~cm}$ segments. The fresh tissue was then secured to a tissue holder and then suspended in a $50 \mathrm{ml}$ isolated organ bath containing freshly prepared physiological solution (Tyrode), $\mathrm{pH}(7.4)$, aerated with $95 \%$ and $5 \% \mathrm{CO}_{2}$ oxygen and maintained at $37^{\circ} \mathrm{C}$. The effects of Adrenaline, Isoprenaline and Extract were tested on strips of jejunum strips while responses were isometrically recorded on recording paper via student physiograph stimulator (Labotech ss-700 BD instrumentation india).

\subsection{Reference Drugs and Reagents}

The drugs and the reagents used were of standard analytical grade- Adrenaline $\left(1 \times 10^{-3} \mathrm{~g} / \mathrm{ml}\right)$ and Isoprenaline $\left(1 \times 10^{-3} \mathrm{~g} / \mathrm{ml}\right)$. The reference drugs were prepared by weighing out and dissolving in required volume of distilled water to give desired stock concentration. Various dilutions from stock were made for each experiment, while Sodium Chloride, Calcium Chloride, Magnesium Chloride, Sodium HydrogenTrioxocarbonate (IV), Sodium Dihydrogen Phosphate and Glucose for preparation of physiological salt solution. These were products of Sigma Chemical Company, Louis, USA, Burgoynes \& Co, India, BDH Chemical Ltd. Poole, England, Kernel Chemicals, Germany and Hopkin \& Williams Ltd. England (Idyu et al, 2014b).

The reference drugs were prepared by weighing out and dissolving in required volume of distilled water to give desired stock concentration. Various dilutions from stock were made for each experiment.

\subsection{Drugs and Crude Extract Investigations}

Drug activities were investigated on the isolated jejunum tissue by way of arithmetic progression volume to obtain dose- responses using varying volumes $(0.1 \mathrm{ml}$, $0.2 \mathrm{ml}, 0.4 \mathrm{ml}$ and $0.8 \mathrm{ml})$ : in the following order:

Adrenaline $\left(1 \times 10^{-5} \mathrm{~g} / \mathrm{ml}\right)$ alone

Isoprenaline $\left(1 \times 10^{-5} \mathrm{~g} / \mathrm{ml}\right)$ alone

E. suaveolens extract $\left(1 \times 10^{-2} \mathrm{~g} / \mathrm{ml}\right)$

\section{Results}

Figure 1, Figure 2, Figure 3 illustrate tracings obtained from administration of Adrenaline, Isoprenaline and of crude extract of stem-back of E. suaveolens respectively. Tables and graphs 1, 2, 3 illustrate same while graph 4 shows the combined plot of the two standard drugs and extract.

\subsection{Tracings Showing the Effect of Drugs on Rabbits Jejunum}

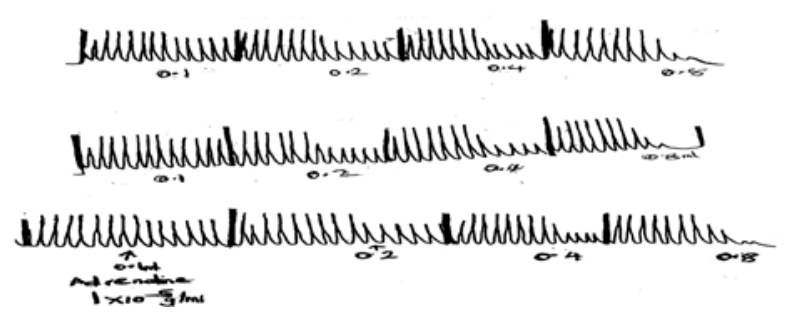

Figure 1. Adrenaline 


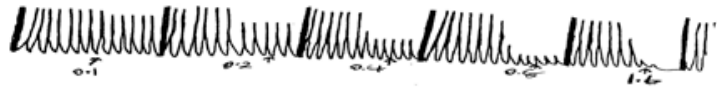

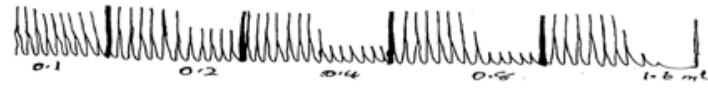

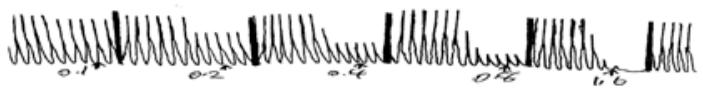

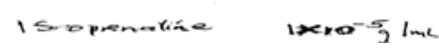

Figure 2. Isoprenaline

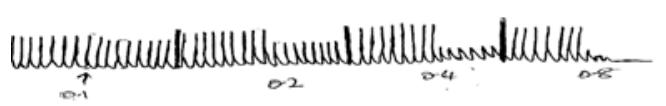

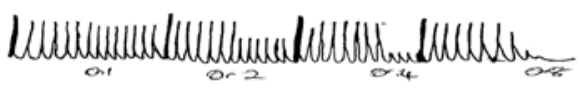

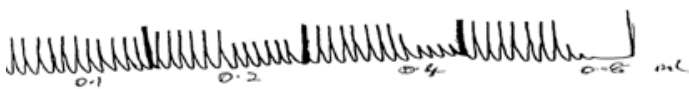

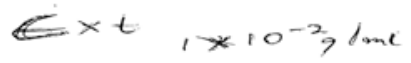

Figure 3. E. suaveolens Extract

\subsection{Dose-response Relationship of Drugs on Rabbits Jejunum}

Table 1. Adrenaline alone

\begin{tabular}{|c|c|c|c|c|}
\hline $\begin{array}{c}\text { Conc. Of } \\
\text { Adr. g/ml) }\end{array}$ & $\begin{array}{c}\text { Vol. of } \\
\text { Adr. }(\mathrm{ml})\end{array}$ & $\begin{array}{c}\text { FBC } \\
(\mathrm{g} / \mathrm{ml})\end{array}$ & $\begin{array}{c}\text { Log } \\
\text { FBC }\end{array}$ & $\begin{array}{c}\text { Mean Inhibition } \\
(\mathrm{cm})(\%) \text { Max. }\end{array}$ \\
\hline $1 \times 10^{-5}$ & 0.4 & $2 \times 10^{-8}$ & -7.69 & 0.3317 .37 \\
\hline $1 \times 10^{-5}$ & 0.6 & $4 \times 10^{-8}$ & -7.39 & 0.7740 .53 \\
\hline $1 \times 10^{-5}$ & 1.0 & $8 \times 10^{-8}$ & -7.09 & 1.0655 .79 \\
\hline $1 \times 10^{-5}$ & 1.8 & $1.6 \times 10^{-7}$ & -6.79 & 1.90100 .00 \\
\hline
\end{tabular}

Table 2. Isoprenaline alone

\begin{tabular}{|c|c|c|c|c|}
\multicolumn{2}{c}{ Table 2. Isoprenaline alone } \\
\begin{tabular}{|c|c|c|} 
Conc. Of \\
Isopr.(g/ml)
\end{tabular} & $\begin{array}{c}\text { Vol. of } \\
\text { Isopr.(ml) }\end{array}$ & $\begin{array}{c}\text { FBC } \\
(\mathrm{g} / \mathrm{ml})\end{array}$ & $\begin{array}{c}\text { Log } \\
\text { FBC }\end{array}$ & $\begin{array}{c}\text { Mean } \\
\text { Inhibition } \\
(\mathrm{cm})(\%) M a x .\end{array}$ \\
\hline $1 \times 10^{-5}$ & 0.1 & $2 \times 10^{-8}$ & -7.69 & 0.3010 .83 \\
\hline $1 \times 10^{-5}$ & 0.2 & $4 \times 10^{-8}$ & -7.39 & 0.9735 .02 \\
\hline $1 \times 10^{-5}$ & 0.4 & $8 \times 10^{-8}$ & -7.09 & 1.5756 .68 \\
\hline $1 \times 10^{-5}$ & 0.8 & $1.6 \times 10^{-7}$ & -6.79 & 2.3083 .03 \\
\hline $1 \times 10^{-5}$ & 1.6 & $3.2 \times 10^{-7}$ & -6.49 & 2.77100 .00 \\
\hline
\end{tabular}

Table 3. Extract alone

\begin{tabular}{|c|c|c|c|c|}
\hline $\begin{array}{c}\text { Conc. Of } \\
\text { Extract (g/ml) }\end{array}$ & $\begin{array}{c}\text { Vol. of } \\
\text { Extract (ml) }\end{array}$ & $\begin{array}{c}\text { FBC } \\
(\mathrm{g} / \mathrm{ml})\end{array}$ & $\begin{array}{c}\text { Log } \\
\text { FBC }\end{array}$ & $\begin{array}{c}\text { Mean } \\
\text { Inhibition } \\
(\mathrm{cm}) \\
(\%) \mathrm{Max} .\end{array}$ \\
\hline $1 \times 10^{-2}$ & 0.1 & $2 \times 10^{-5}$ & -4.699 & 0.178 .95 \\
\hline $1 \times 10-^{2}$ & 0.2 & $4 \times 10^{-5}$ & -4.39 & 0.7036 .84 \\
\hline $1 \times 10^{-2}$ & 0.4 & $8 \times 10^{-5}$ & -4.09 & 1.2766 .84 \\
\hline $1 \times 10^{-2}$ & 0.8 & $1.6 \times 10^{-4}$ & -3.80 & 1.90100 .00 \\
\hline
\end{tabular}

\section{Graph 1:}

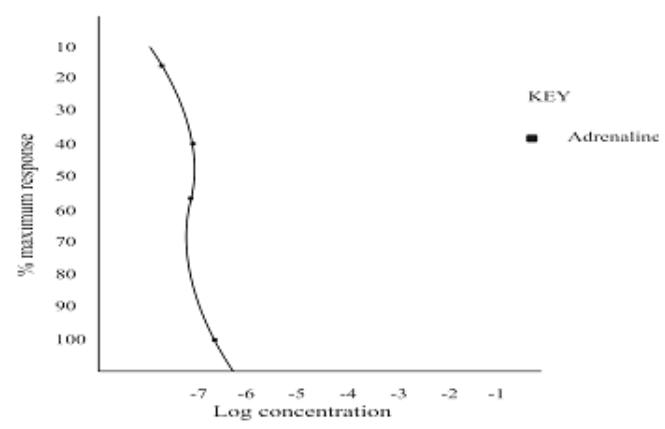

Graph 2:

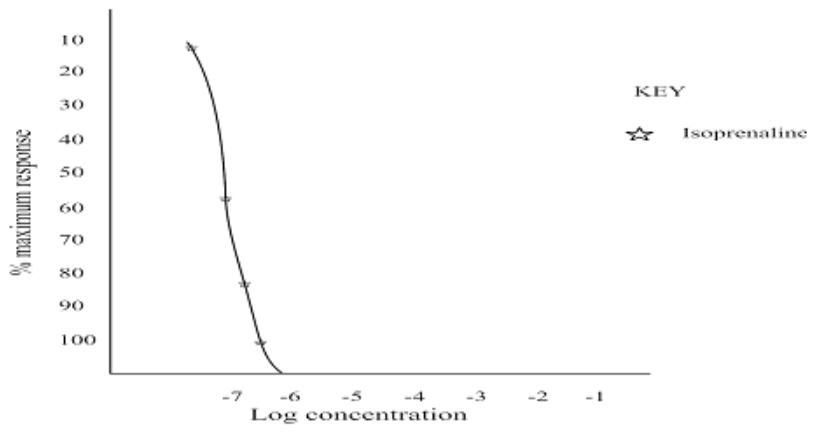

Graph 3:

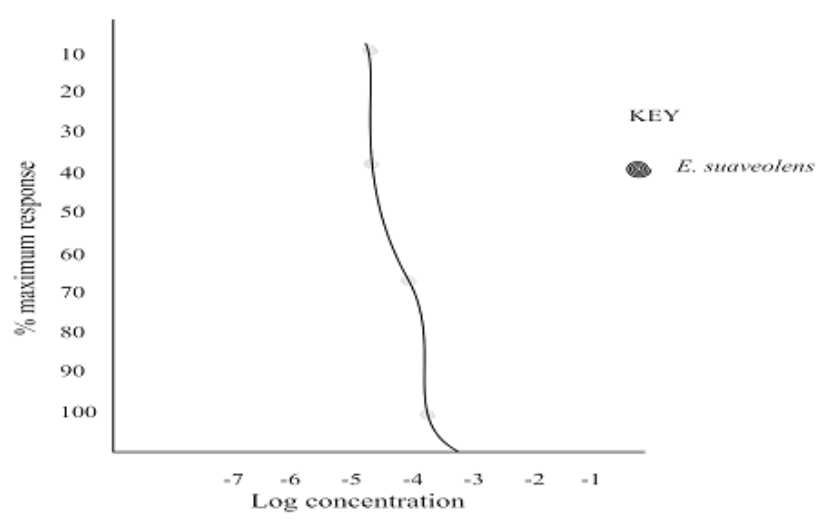

Graph 4:

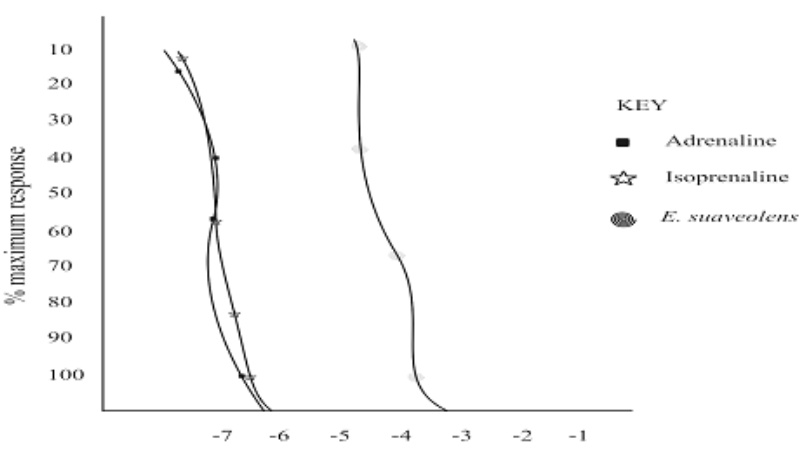

\section{Discussion}

Effects of standard drugs and E. suaveolens on the isolated tissue are highlighted bellow:

\subsection{Adrenaline}

The effect of adrenaline on the isolated rabbit jejunum, which acts on the $\beta_{2}$ receptors, was gradual inhibition. At lower doses, the inhibition were minimal, thus a doses dependent inhibitory rhythmic activities as expected (Table 1; Figure 1; Graph 1).

\subsection{Isoprenaline}

The drug acts through the $\beta_{2}$ receptors on the rabbit jejunum. A gradual inhibition was observed also with minimal inhibition at lower doses and blockade of rhythmic activity of same isolated tissue at higher doses as expected (Table 2; Figure 2; Graph 2). 


\subsection{Extract}

The effect of the Erythrophleum suaveolens extract on the isolated rabbit jejunum was also a gradual inhibition as at lower doses, the inhibition was minimal and at higher doses, reduced rhythmic activities, thus a blockade.

Preliminary pharmacological investigation of the extract revealed inhibitory effect agrees with Idyu 2014b. This suggests that the extract interfered with the mechanism(s) of the jejunal rhythmic activity. Extract has an anti-diarrheal tendency due to the inhibitory nature hence may contain flavonoid. The presence of flavonoid in plant extract could be responsible for their antidiarrheal activities. This justifies the ethno medicinal use of the plants [22].

The therapeutic effect could also be due to its antimotility and anti-secretary properties. A comparison of pre- and postsynaptic activities of drugs in one and the same tissue has been carried out previously in experiments on peripheral adrenergic neuroeffector junctions [15]. Fozard and Muscholl found similar potencies for pre- and postsynaptic effects of a series of muscarinic agonists in the perfused rabbit heart. They, therefore, concluded that similar receptors mediate inhibition of arterial tension, ventricular rate and neuronal nor-adrenaline release [23].

\section{Conclusion}

The gradual inhibitory effect at lower doses and minimal / reduced rhythmic activities exhibited by the cold water bark extract of E. suaveolens on the isolated rabbit jejunum compares with that of the standard drugs (Adrenaline and Isoprenaline) thus, portray dose dependent inhibitory rhythmic activities. However, the relaxative effect of the extract on isolated smooth muscle was confirmed from its cumulative response on Rabbit jejunum in which there was a graded inhibition of the jejunal contraction even up to 95\% - 95.5\%. The result of the study therefore suggest that the extract has the potential of been develop as an anti-motility agent as a remedy for GIT system related problems.

\subsection{Recommendation}

Further studies on phytochemistry and confirmation on the anti-diarrheal activities as well as the effect on other smooth and skeletal muscles are recommended.

\section{Acknowledgement}

Prof. E.N Sokomba, Prof. Alhassan Yakubu, Prof. S.W Husseni, Prof. F.I Anjorin, Assoc. Prof. Chris Isichie, Assoc. Prof. F. O Asalu, Mr. Okonkwo, Mr. Gaiya Abishai Auta and Mr William J.C.

\section{Conflicting Interest}

No conflict of interest.

\section{References}

[1] Nwinyl FC and Kwanashie: comparative effects of sorghum bicolor leaf base extract on tissues isolated from some body system of experimental animals. J. of Med Plants Res. Vol. 7 (41), 3 Nov. 2013, pp. 3041-305.

[2] Abelson, PH. Medicine from plants. Science 2: 247, 1990.

[3] Nwude N, Chineme CN. Toxic effects of the leaves of E. africanum (Harms) in sheep. Bull. Anim. Health Product. Afr., 229: 3499-3500, 1981.

[4] Holmsttedt. Ordeal poison. Int. Journ. of ethnopharmacology, 63: 20-21, 1972.

[5] Akinpelu BA, Dare CA, Adebesin FI, Iwalewa EO, Oyedapo OO. Effect of stem - bark of Erythrophleum suaveolens (Guill. \& Perri.) saponin on fresh water snail (Lanistes lybicus) tissues. Afric. J. Environmental Sci. \& Tech. Vol. 6 (11): 446-451, 2012.

[6] Burkill H. The Useful Plants of West Tropical Africa. Vol. 3, 116120, 1985.

[7] Guil and Perr. J. ethno-pharmacology. 63, 1960.

[8] Aubreville. As E. guineense G Don. 241, 1950.

[9] (a) Idyu II, Olaoye TO, Sokomba EN, Idyu VC, Ramyil MS, Ogbole EA, Builders MI, Ogundeko TO. The Pharmacological evaluation of cold water stem-bacrk extract of Erythrophleum suaveolens on gastrointestinal muscle of guinea pig (Cavia porcellus) ileum. IJSR vol. 3 issue 5: 020131788, pp. 602-607, 2014. www.ijsr.net. (b) Idyu II, Kela SL, Idyu VC, Akinyede A, Builders MI, Ogbole EA, Ramyil MS, Ogundeko TO. Acute Toxicity Studies of Erythrophleum suaveolensin Albino Mice (Mus musculus). IJSR vol. 3 issue4: 020131424, pp. 366-371, 2014. www.ijsr.net.

[10] Ahlquist RP, Levy B. Adrenergic receptive mechanism of canine ileum. J. Pharmacol. Exp. Ther., 127, 146-149, 1959.

[11] Furchgott RF. Receptors for sympathetic amines. In adrenergic mechanisms, Ciba Foundation Symposium, ed. Vane JR, Wolstenholm GEW \& O’Connor CM London: J \& A, Churchill, 1960.

[12] McDougal MD, West GB. The action of Isoprenaline on intestinal muscle. Archs int. Pharmacodyn. Ther., 90, 86-92, 1952.

[13] McDougal MD, West GB. The inhibition of the peristaltic reflex by sympathomimetic amines. Br. J. Pharmac. Chemother., 154, 463-471, 1954.

[14] Kosterlitz HW, Robinson JA. Inhibition of the peristaltic reflex of the isolated giunea-pig ileum. J. Physiol., Lond., 136, 249-262, 1957.

[15] Kilbinger H, Wessler I. Pre- and postsynaptic effects of muscarinic agonists in the guinea-pig ileum. NaunynSchmiedeberg's Arch. Pharmacol., 314, 259-266, 1980.

[16] Kosterlitz HW, Watt AJ. Adrenergic receptors in the guinea-pig ileum. J. Physiol., Lond., 177: 11-12, 1965.

[17] Kosterlitz HW, Lydon RJ. The actions of choline, adrenaline and phenoxybenzamine on the innervated longitudinal muscle strip of the guinea-pig ileum. Br. J. Pharmac. Chemother., 32: 422, 1968.

[18] Kosterlitz HW, Lydon RJ, Watt AJ. The effect of adrenaline, noradrenaline and Isoprenaline on inhibitory $\alpha-$ and $\beta$ adrenoreceptors in the longitudinal muscle of the guinea-pig ileum. Br. J. Pharmac., 39, 398-413, 1970.

[19] Kosterlitz HW, Cowie AL. Some actions of transmission at the nerve- smooth muscle junction in the longitudinal muscle of the guinea-pig ileum. Am. J. dig. Dis., N.S., 13, 415-417, 1968.

[20] AA Ahmadu, AU Zezi, and AH Yaro. Anti-diarheal activity of the leaf extracts of Daniellia oliveri Hutch and Dalz (Fabaceae) and Ficus sycomorus miomoraceae. Afr. J. of Trad, Compl and Alt Med, vol. 4, 44.2007, pp. 524-528.

[21] Couper IM. Opiod cts on the intestine, the importance of the intestinal mucosa. Life Sci. 41: 917-925, 2007.

[22] Samuelson G. Nature as sources of drugs. Acta pharmaceutica mordica., 1: 111-116, 1989.

[23] Fozard JR, Mushcholl E. Effects of several muscarinic agonists on cardiac performance and the release of noradrenaline from sympathetic nerves of the perfused rabbit heart. Br. J. Pharmacol., 45: 616-629, 1972. 